THE SKEPTICAL PUBLIC: ECONOMIC CONDITIONS AND INDIVIDUAL TRADE POLICY PREFERENCES

\author{
BY \\ C2010 \\ ABRAHAM T. MATHEW
}

Submitted to the graduate degree program in Political Science and the Graduate Faculty of the University of Kansas in partial fulfillment of the requirements for the degree of Masters of Arts

$$
\text { Chairperson* }
$$

Date Defended: 
The Thesis Committee for Abraham T. Mathew certifies that this is the approved Version of the following thesis:

\title{
THE SKEPTICAL PUBLIC: ECONOMIC CONDITIONS AND INDIVIDUAL TRADE POLICY PREFERENCES
}

\author{
Committee:
}

\author{
Chairperson*
}

Date approved: 


\begin{abstract}
:
Public opinion literature has shown that the foreign policy attitudes of the American electorate are ideologically coherent and are fairly stable over long periods of time. Research also determined that a number of social and political factors influence public opinion. However, little attention has been paid to the relationship between economic conditions and public opinion. This study uses survey data from the American National Election Study (ANES) to determine whether the economic environment influences public support for new limits on foreign imports. My analysis suggests that economic conditions are a statistically significant predictor of trade preferences in only two of my five logit models. The results lead me to infer that economic conditions have little impact on individual trade policy preferences. In contrast, I find that education and gender are important predictors of trade preferences. Future studies should consider additional ways that economic conditions might influence public attitudes on trade and other foreign policy issues.
\end{abstract}




\section{Introduction}

In recent decades, the literature analyzing public opinion and U.S. foreign policy has undergone tremendous growth (Meernik and Ault 2001, 352). Most of this new research has determined that the American public is "capable of thinking in an informed, coherent, ideological way about public policy" (Moe 2001, 194). Although early public opinion research found that the electorate was uninformed about politics, recent survey research suggests that the public is not as ignorant, unsophisticated, and apolitical as was previously thought. Meernik and Ault $(2001,352)$ contend that "public opinion on foreign policy issues is essentially competent and consequential in the U.S. political system."

Scholars have also found that changes in public opinion were usually rational (Page and Shapiro 1982) and occur in response to important political events (Wlexien 1995). Furthermore, recent research suggests that changes in the political environment can affect aggregate public opinion if those changes are communicated to the public by the mass media (Stevenson 2001, 622). Nevertheless, little attention has been paid to whether changes in the economic environment influence public opinion. Although some scholars have looked at the impact of economic conditions on aggregate public opinion (Durr 1993; Stevenson 2001), more research is needed. In particular, public opinion scholars must consider whether changes in the economic environment impact public attitudes towards specific policy issues.

In this study, I utilize survey data from the American National Election Study (ANES) to determine whether perceived economic conditions influence individual 
trade policy preferences. Trade preferences are measured using a survey question which asks respondents about support for new trade barriers. I assume that individuals who support international trade will report that they oppose new limits on foreign imports, while individuals who oppose international trade will report that they favor new limits on foreign imports. Economic conditions are measured using survey questions which ask respondents to evaluate changes within the economic environment over the past year. I examine the influence of both personal and national economic perceptions on individual trade policy preferences.

Using logistic regression, I find that economic conditions apparently have little impact on public support for new limits on foreign imports. Economic conditions are statistically significant in only two of my five logit models. In these models, I find that positive economic evaluations are associated with pro-trade attitudes. My analysis also shows that education and gender are important predictors of individual trade policy preferences. These findings suggest that people do not alter their trade preferences regardless of if they believe economic conditions have improved or deteriorated.

This paper proceeds as follows. In section two, I provide a brief introduction to trade policy and consider what surveys indicate about public attitudes towards international trade. Section three reviews major research on American public opinion and foreign policy. Section four looks at research on the political and economic factors which influence public opinion. Section five introduces the data and outlines 
my strategy for analyzing the research question. In sections six, I report the findings of this analysis and discuss the broader implications of this study.

\section{Background}

International trade involves the exchange of capital, goods, and services across national borders. The United States (U.S.) has traditionally been a leading proponent of market liberalization and free trade. From the conclusion of the Second World War through the 1970s, the U.S. advanced a series of proposals designed to systematically reduce trade barriers and encourage multilateralism (Destler 2005). These policies contributed to a significant increase in the world's trade volume (Cunat and Maffezzoli 2007, 583). From 1973 until today, international trade grew at a pace of $11 \%$ annually, rising from just over $22 \%$ of world GDP to $42 \%$ today (Estevadeordal and Taylor 2002). Since 1973, the flows of capital between countries have also exploded, rising from 5\% of world GDP to $21 \%$ today (World Bank 2004). Scholars argue that the reduction of tariffs was one of the most important contributors to the rise in international trade (Baier and Bergstand 2001). The global trend towards market liberalization is responsible for producing an unprecedented era of world economic growth (Bradford et al, 2006).

According to economic theory, countries engage in international trade because it is mutually beneficial. The theory of comparative advantage contends that if "countries specialize in areas where they have a comparative advantage and they freely trade goods and services over the long run, all nations involved will gain greater wealth" (Aspray et al. 2006, 3). Likewise, Destler $(2005,4)$ explains that "by 
participating in a broader community within which individuals and groups sell what they can produce with the greatest (comparative) efficiency, people can secure a far greater quantity and variety of goods than each individual could possibly obtain if they had to produce every one themselves." Studies have found that international trade raises income levels (Frankel and Romer 1999), increases economic output (Wacziarg and Welch 2008), and produces greater import variety (Broda and Weinstein 2006). Furthermore, trade protectionism has a negative impact on economic growth and hurts consumers by producing higher prices (Lenway et al. 1990). Scholars also argue that trade has a limited impact on U.S. job displacement and wage inequality (Baldwin and Cain 2000). These studies show that the global expansion of international trade has greatly benefited the United States and its trading partners (Krol 2008).

Over the past few years, public opinion polls in the U.S. have shown that there is significant opposition to policies aimed at further liberalization of international trade and foreign direct investment (Scheve and Slaughter 2001b, 1). Public support for engagement with the global economy has declined in recent years (Scheve and Slaughter 2007, 35). Survey results presented in Scheve and Slaughter (2001b) suggest that a majority of the American public is concerned about the impact of free trade on the U.S. labor market. Furthermore, they find that a majority of Americans have been opposed to trade liberalization since the 1970s (Scheve and Slaughter, 2001b). Although the American public is generally uninformed about how the economy operates (Blinder and Kruger 2004; Walstad 1996), Scheve and Slaughter 
(2001b) argue that these perceptions are not the result of public ignorance about the benefits of international trade. In fact, many of these survey respondents also recognized that the U.S. benefits from international trade (Scheve and Slaughter 2001b, 9). Survey results presented in O'Rourke and Sinnott (2002) suggest that a majority of survey respondents in the U.S. and twenty two other Western democracies favor imposing new limits on foreign imports. Although the American public is skeptical of free trade, scholars acknowledge that most Americans have a favorable perception of both capitalism and the private sector (McClosky and Zaller 1984).

Public opinion research on trade preferences has traditionally been concerned with documenting the scope of public opposition to international trade. For example, Bauer, Pool, and Dexter (1963) explain that opposition to international trade was prevalent throughout the 1950s and 1960s. However, a number of studies have used survey data to identify the determinants of individual trade policy preferences. These studies looked at whether support for international trade was concentrated in particular socioeconomic or demographic groups. Using ANES survey data from 1992 and 1996, Scheve and Slaughter (2001a) examined the influence of industry of employment, factor type, and "human capital"/skills (measured by years of education) on individual trade policy preferences. They found that individuals with lower skills were more likely to support imposing new restrictions on foreign imports than those with higher skills. Scheve and Slaughter (2001a, 9) conclude that individual trade policy preferences are strongly aligned with labor market skills. Many other studies 
have determined that more education and higher labor skills are associated with protrade attitudes (Hainmueller and Hiscox, 2006; Hoffman, 2007; O'Rourke, 2003).

Hoffman determined that Democrats are generally more pro-trade than Republicans. He found that public attitudes about international trade are determined by a combination of economics, politics, and knowledge. Working with survey data collected by the International Social Survey Programme (ISSP), Mayda and Rodrik (2004) found that attitudes toward trade are correlated with an individual's level of human capital (measured by years of education). Industry of employment was another important predictor of trade preferences. Individuals employed in non-traded sectors tend to be the most pro-trade, while individuals in sectors with a revealed comparative disadvantage are the most protectionist (Mayda and Rodrik 2004, 28). Mayda and Rodrik $(2004,29)$ account for a number of non-economic determinants and find that high degrees of neighborhood attachment and nationalism/patriotism are associated with protectionist tendencies, while cosmopolitanism is correlated with pro-trade attitudes. Likewise, Granzin et al (1997) determined that persons with lower educational achievement and those who engage in social categorization that unfavorably distinguishes out-groups are more likely to oppose international trade.

Other public opinion studies have established that survey respondents who were more resentful of modern life, more suspicious of consumerism and the free market, and believed that their traditional way of life is disappearing were more likely to have negative opinions about both economic and cultural globalization (Edwards 2006, 603). Furthermore, individuals who are "heavy consumers of exportable goods 
are more protectionist than heavy consumers of imports and import-competing goods" (Baker 2005, 924). This suggests that varying consumer tastes may be a potential source of beliefs about trade policy (Baker 2005, 924). Issue frames may also have a powerful effect on public attitudes regarding international trade (Hiscox, 2006). In his survey experiment, Hiscox (2006) found that respondents were less likely to favor increasing trade with other countries when they are presented with anti-trade arguments. Support for international trade increased when respondents were informed that most leading economists endorse free trade (Hiscox 2006, 777). Furthermore, Hiscox found that the responses of less educated survey respondents were more sensitive to framing effects than those of highly educated individuals. While research in this area is still developing, these early studies provide us with important generalizations regarding the determinants of attitudes toward international trade (Hoffman 2009, 456).

\section{Literature Review: Public Opinion and Foreign Policy}

Early public opinion research found that the American electorate lacks both political knowledge and genuine policy preferences. Scholars believed that the common man was more concerned about satisfying his immediate needs than being politically engaged. As a result, proponents of minimalism argued that most Americans react to foreign policy issues in an emotional and unreasoned manner (Knopf 1998, 544). Almond (1950) and Lippmann (1955) characterized American public opinion as "not only ignorant about international realities, but also as volatile, reflecting unstable moods of the moment rather than an understanding of international 
realities, as well as lacking in any structure or coherence" (Holsti 1996, 19).

Furthermore, scholars claimed that public opinion has a very limited impact on the conduct of foreign policy (Holsti 1992, 442). For decades, this minimalist perspective was the accepted wisdom among public opinion scholars (Knopf 1998, 544).

Using survey data from the 1950s and 1960s, the authors of The American Voter painted an unflattering portrait of American public opinion. When asked to acknowledge the existence of specific policy issues, a significant portion of the survey respondents were unable to identify major policy issues (Campbell et al. 1960, 170). Likewise, Converse (1965) found that large segments of the electorate were unfamiliar with many prominent political issues. Converse $(1965,243-244)$ explained that large portions of the electorate "do not have meaningful beliefs, even on issues that have formed the basis for intense controversy among elites for substantial periods of time." Working with survey data collected by the National Election Study (NES), he noticed little evidence of ideological coherence in American public opinion because survey responses varied dramatically from one survey to the next. There was low correlation across survey responses to questions on both domestic and foreign policy issues (Holsti 2002, 32). Furthermore, most Americans did not hold consistent preferences over time. These results led Converse to characterize mass political beliefs as "non-attitudes."

Minimalism has been strongly challenged in recent decades (Johns 2009, 575). New research found that the foreign policy attitudes of the electorate are structured according to coherent belief systems (Verba et al 1967; Achen 1975; 
Maggiotto and Wittkopf 1981) and are fairly stable over long periods of time (Key 1961; Caspary 1970; Peffley and Hurwitz 1987). Empirical studies also found greater ideological consistency among the general public during the 1960s and 1970s (Nie et al. 1979). Furthermore, research on public opinion change have emphasized that short term changes in aggregate opinion are usually rational (Page and Shapiro 1982; Wlezien 1995). Empirical studies found that changes in opinion usually occurred as a response to important foreign policy events (Peffley and Hurwitz 1992; Holsti 1996). According to Page and Shapiro $(1982,34)$, all rapid shifts in public opinion "were related to political circumstances or significant events which sensible citizens would take into account."

Critics of minimalism contend that ordinary citizens are capable of "making sense of the political world despite their lack of detailed information about ideologies, policies, and candidates” (Bartels 1996, 196). Using survey data from Gallup, Mueller (1971) examined the impact of casualties on public support for the Vietnam and Korean Wars. Support for the each war dropped as the number of American casualties increased. While public attitudes about each conflict changed over time, these changes were not random and mindless (Holsti 1992, 446). In The Rational Public, Page and Shapiro (1991) examined more than 6,000 survey questions from the mid-1930s through the 1980s and found that aggregate public opinion was characterized by a good deal of stability. Moreover, public attitudes about domestic and foreign policy issues were equally stable. While opinion is stable and coherent, the public is generally uninformed about most political issues. As a result, the public 
utilizes information shortcuts to understand political events (Lupia 1994; Lau and Redlawsk 2006). Popkin $(1994,7)$ explains that people draw on various information shortcuts and rules of thumb in order to obtain and evaluate information and to simplify the process of being politically informed.

\section{Literature Review: Economic Conditions and Public Opinion}

Many social, political, and economic factors influence public opinion.

Abramowitz (1987) and Shaw (1999) found that presidential campaign events have a strong impact on how the public evaluates candidates. Furthermore, media exposure (Page et al. 1987) and issue frames (Nelson and Oxley 1999) shape how individuals understand political events. Public preferences are also influenced by policy outcomes (Hoekstra 2003) and religious beliefs (Jelen 1994). These studies show that although public opinion is not volatile and does not fluctuate wildly, it is also not stagnant and inactive.

Scholars argue that "changes in the political environment will be systematically reflected in aggregate opinion if those changes are communicated to the public by the mass media" (Stevenson 2001, 622). When presented with new information about salient political issues, citizens are capable of making adjustments to their preferences (Wlezien 1995; Eichenberg and Stoll 2003). Using survey data from 1973 to 1991, Wlezien (1995) found that the public modifies its preferences in response to changes in defense appropriations. He explains that the "public adjusts its preferences for more spending downward when appropriations increase, and vice versa" (Wlezien 1995, 998). Although scholars have long assumed that policy 
preferences are unaffected by factors within the political system, these findings suggest that public opinion is endogenous to the political environment. Changes in public opinion occur in part as a reaction to developments within the political environment.

While research has determined that a number of political factors shape and influence public opinion, little attention has been paid to the relationship between economic conditions and public opinion. In particular, scholars have not examined whether changes in the economic environment produce changes in aggregate public opinion. This lack of research is surprising because economic factors have long been an important explanatory variable for understanding political phenomena. Scholars acknowledge that it is difficult to empirically examine political phenomenon without considering the impact of economic factors (Durr 1993, 158).

Research on the relationship between economic conditions and public opinion has generally focused on how changes in macro-economic performance influence the "public's mood - an aggregate measure of the public's preferences" (Enns and Kellstedt 2008, 433). Durr (1993) and Stevenson (2001) propose that the policy mood of the American public moves left when the economy is expanding and right when the economy is contracting. Their hypothesis is based on the assumption that a liberal policy agenda is more expensive than a conservative policy agenda. Therefore, Durr argues that citizens are more likely to support expensive liberal policies as economic security increases. When the public believes that they have reached a sufficient level of economic comfort, they are more willing to support policies which assist the poor 
(Durr 1993, 159). In contrast, people are more likely to favor a conservative policy agenda when economic security declines. Durr's empirical analysis found that changes in economic expectations are closely related to changes in Stimson's (1998) measure of policy mood (Stevenson 2001, 622). Stevenson (2001) examined whether changes in the aggregate policy preferences of citizens in fourteen Western democracies were systematically related to national economic performance. He found that a good economic environment pushes policy mood to the left while a poor one pushes it to the right (Stevenson 2001, 632).

While Durr (1993) and Stevenson (2001) establish that there is strong relationship between economic conditions and the public's mood, more research is needed. In particular, scholars must look at the effect of changes in the economic environment on public attitudes towards specific policy issues. It is possible that changes in economic performance will affect certain policy preferences and not others. For example, an economic contraction might have a greater impact on public attitudes about monetary policy than public opinion regarding morality policy. Erikson et al (2002) and Blekesaune (2007) find that periods of economic duress are associated with greater public support for welfare policies. Public support for liberal welfare policies increases when economic conditions deteriorate (Kam and Nam 2007). These studies show that public attitudes about certain policy issues do not move to the right when the economy is contracting. Therefore, research on the relationship between economic performance and public opinion should consider how 
changes in the economic environment influence public attitudes towards different policy domains.

\section{Research Design}

My analysis contributes to this literature by looking at the impact of economic conditions on public support for international trade. I examine trade policy because it has an significant influence on the economic performance of a country. Furthermore, international trade and globalization have become increasingly contentious political issues with the U.S. over the past two decades (Destler 2005). I propose the following hypothesis: public support for imposing new limits on imports will increase when the public believes that economic conditions have deteriorated. Public support for imposing new limits on imports will decline when the public believes that economic conditions have improved. I expect that economic conditions will have a significant impact on individual trade policy preferences.

This study uses survey data to examine whether economic perceptions influence public support for imposing new limits on foreign imports. The data utilized in this paper was collected by the American National Election Study (ANES) ${ }^{1}$. The ANES is a reliable source for public opinion data and is widely used by scholars across a number of academic disciplines. I use this dataset because it contains items which allow me to examine American public attitudes regarding international trade.

\footnotetext{
${ }^{1}$ ANES "surveys are fielded in the United States around the time of presidential elections" and are "designed to gather data on Americans" social background, political predispositions, opinions on questions of public policy, and participation in public life" (Hainmueller and Hiscox 2006, 475).
} 
Furthermore, this dataset contains questions which ask respondents to evaluate economic conditions.

Support for international trade is measured using responses to the following question from the 1996, 1998, 2000, 2004, and 2008 ANES surveys: "Some people have suggested placing new limits on foreign imports in order to protect American jobs. Others say that such limits would raise consumer prices and hurt American exports. Do you favor or oppose placing new limits on imports, or haven't you thought much about this?" Similar versions of this question appear in each ANES survey. Respondents are asked to report their general position on U.S. trade policy (Scheve and Slaughter 2001a, p.276). Therefore, one of the strengths of this survey question is that it does not refer to a specific country, trade agreement, or international organization. I chose to examine these five years because they allows us to consider how different economic conditions influence trade preferences. Because this survey data is cross sectional, my analysis focuses only on the link between economic conditions and public opinion in these five specific years.

For each survey year, I develop a dichotomous dependent variable, trade opinion, which is coded 1 for responses that favored "new limits on foreign imports" and 0 for those opposed. The "haven't thought much about this" answers are coded as missing. I assume that individuals who support international trade will report that they oppose new limits on foreign imports, while individuals who oppose international trade will report that they favor new limits on foreign imports. My coding scheme is identical to the approach utilized by Scheve and Slaughter (2001a) 
in their influential study on individual trade policy preferences. This survey data shows that a significant portion of the American public is opposed to international trade. In the 1996, 1998, 2004, and 2008 ANES surveys, a majority of respondents report that they favor imposing new limits on foreign imports. Furthermore, support for international trade was highest in 1998 and lowest in 2008.

Economic conditions are examined using survey questions which ask respondents to evaluate their economic environment. Survey respondents report whether economic conditions have improved over the last year, stayed about the same, or gotten worse. I consider the effect of both personal and national economic evaluations on public support for international trade. Research indicates that these two factors have an impact on various political phenomena (Campbell et al. 1960; Kinder and Kiewiet 1979). I measure personal economic conditions using responses to the following question: "We are interested in how people are getting along financially these days. Would you say that you (and your family living here) are better off, worse off, or just about the same financially than you were a year ago?" The "better off" responses are coded 1, "worse off" are coded 3, and "the same" are coded 2. National economic conditions are measured using responses to the following question: "Now thinking about the economy as a whole, would you say that over the past year the nation's economy has gotten better, stayed about the same, or gotten worse?" The "gotten better" responses are coded 1, "gotten worse" are coded 2, and "stayed about the same" are coded 3. Similar versions of each question appear in the 1996, 1998, 2000, 2004, and 2008 ANES surveys. 
Both of these survey questions allow us to gauge how respondents perceive changes in the economic environment over the last year. As a result, I am able to determine whether a positive or negative shift in economic perceptions is related to greater or lesser public support for international trade. My primary independent variables are finances and economy. A majority of respondents from the 1996, 1998, and 2000 ANES surveys report that the U.S. economy has either gotten better over the past year or stayed about the same. However, survey respondents had a more negative perception of the countries economic performance in 2004 and 2008. More survey respondents also report that their personal financial well-being was worse in 2004 and 2008 than in 1996, 1998, or 2000. This survey data suggests that the public perceived economic conditions to be positive in 1996, 1998, and 2000, and negative in 2004 and 2008. These two variables allow us to examine whether support for international trade declines in those years where the public believes that economic conditions have deteriorated.

I also control for the influence of various respondent characteristics, including age, education, partisan affiliation, race, gender, employment, and income. These independent variables are included in this study primarily as control variables and are not the focus of my analysis. However, research shows that a number of these factors have a significant effect on individual trade policy preferences. For example, I expect that individuals with a college education will be more likely to support international trade than those with just a high school education (Bauer, Pool, and Dexter 1972, 8184). Scholars have traditionally assumed that people who have earned a college 
degree are "far more informed than others about the aggregate efficiency gains associated with expanded trade" (Hainmueller and Hiscox 2006, 472). Others propose that increased education "tends to socialize students to have more tolerant, cosmopolitan views of the world" (Hainmueller and Hiscox 2006, 472). Furthermore, women are less likely than men to support increasing trade with foreign nations (Burgoon and Hiscox 2004).

I also account for the influence of union membership, home ownership, and support for free market capitalism. While these three factors are not my principal independent variables, they may have an important effect on individual trade policy preferences. Home ownership is measured using responses to the following question: Do you own your home, pay rent, or what? The "own home" responses were coded 1, "pay rent" were coded 2, and "other" were coded as missing. I expect that homeowners will be more likely than renters to support international trade (Scheve and Slaughter 2001b). Support for free market capitalism is measured using a survey question in which respondents are asked to pick one of the following: "One, we need a strong government to handle today's complex economic problems, or Two, the free market can handle these problems without government being involved." People with a more favorable opinion of free market capitalism should be more likely to oppose placing new limits on foreign imports. I measure union membership using responses to the following question: "Do you or anyone else in this household belong to a labor union?" The "yes" responses were coded 1 and "no" are coded 2. Individuals with lower labor skills are more likely to support restrictions on imports than those with 
higher skills (Scheve and Slaughter 2001). Therefore, membership in a union should also be associated with support for imposing new limits on foreign imports.

This study uses a logistic regression to estimate the influence of economic perceptions on public support for international trade. I construct a logit model because the dependent variable, trade opinion, has dichotomous response categories (Hosmer and Lemeshow 2000; Fox 2000). I model attitudes for each survey year. The results of each logistic regression model are presented in Table 2.

As with any empirical analysis, the models estimated here have a number of limitations. First, the data used in this study is cross-sectional and does not allow me to examine real changes in public opinion over time. Because of these data limitations, this analysis can only comment on whether economic perceptions influence individual trade policy preferences in five specific years. Furthermore, this study does not utilize a hierarchical model to account for the impact of actual economic indicators on trade preferences. Instead, I measure economic conditions using survey data which asks respondents to report their evaluation of the economic environment. This may adversely affect my results if the public misperceived economic conditions. Likewise, I am unable to account for the impact of political bias on economic evaluations (Duch et al. 2000). Finally, I only look at the effect of economic conditions on a single public policy, international trade. As mentioned earlier, changes in the economic environment may have a different impact on public attitudes towards other policy issues. However, I do not look at other policy issues in 
this study. My regression model should be viewed in light of these potential limitations.

\section{Results and Discussion}

The results of my logit model for 1996 are presented in Model 1 of Table 2. The primary independent variables, finances and economy, are statistically significant and possess negative coefficients. For every one unit increase in an individuals evaluation of national and personal economic conditions, the log-odds of support for "placing new limits on imports" decreased by 0.46 and 0.20 . Based on these estimates, I propose that survey respondents who had a positive evaluation of economic conditions were less likely to oppose international trade in this survey year. Model 1 also reveals that the controls for education, market, and income are important predictors of individual trade policy preferences. Income is positively correlated with support for international trade. Furthermore, people who support free market capitalism were more likely to oppose new restrictions on foreign imports.

Model 2 in Table 2 presents the results of the logit model for 1998. The variables which are of concern to my hypothesis were not statistically significant. However, the control variables for age, education, partisanship, and gender are all significant at the 5\% level. I find that support for international trade was higher among younger persons. Surprisingly, all the variables considered in Model 3 emerged as statistically insignificant and are unable to account for trade policy preferences in 2000. One possible reason for this outcome could be the existence of excessive missing observations within the recoded survey data. In any case, this 
model also shows that the variables education and economy possess .06 p-values and have negative coefficients. Although not statistically significant, these estimates indicate that there is a minimal correlation between these predictors and trade attitudes. In Model 4, my primary independent variables are once again not correlated with support for international trade. However, the logit estimates show that age, education, economy, employment, market, and gender are statistically significant. In my final model, the only variables which appear to be correlated with trade preferences are gender and education.

Across all five years, I found that economic conditions were not a consistent predictor of individual trade policy preferences. The variable economy was significant in two models, 1996 and 2004, and finances was only significant in the 1996 model. In the other logit models, these primary variables possess low p-values but are not statistically significant at the $5 \%$ level. These results confirm that economic conditions have little influence on public attitudes towards international trade policy. Economic conditions had a significant influence on trade preferences in just $40 \%$ of the cases examined in this analysis. However, my analysis determined that education was an important predictor of individual trade policy preferences. Furthermore, gender was also significant in three of the five logit models. Women were more likely to favor placing new limits on foreign imports than men. One of the most surprising findings of this analysis was that home ownership and union membership were not significant in any of my regression models. I expected that renters and members of a union would be more likely to favor trade protectionism. 
In order to develop a stronger understanding of the influence of economic conditions on trade preferences, I utilize post-estimation strategies to simulate the predicted probabilities of support for new limits of foreign imports based on evaluations about personal and national economic conditions. I hold all other variables constant. Predicted probabilities are developed only for the two years in which economic conditions appear to be significant predictor of trade policy preferences. I also developed predicted probabilities for the variable education, which was found to be a significant predictor of trade policy preferences in four of the five logit models. Therefore, I believe that it is necessary to examine the probabilities of support for new limits on foreign imports based on respondents' educational achievements. Probabilities are developed for the four models in which education appears to be an important predictor of individual trade policy preferences.

Table 3 shows that respondents who believed that economic conditions had improved in 1996 were 54\% (+/- 2\%) more likely to oppose new limits on foreign imports. On the other hand, individuals who report that national economic conditions have gotten worse over the past year were predicted to oppose international trade a mere $32 \%(+/-3 \%)$ of the time. This is a change in average probability of $22 \%$. Those who claim that their personal finances had improved were predicted to oppose new limits on foreign imports $50 \%(+/-2 \%)$ of the time while those were report that their personal finances had gotten worse were predicted to oppose trade barriers $45 \%(+/-$ $1 \%$ ) of the time. Furthermore, the predicted probabilities for the 2004 model show that respondents who believed that the national economy had gotten better over the 
past year were more likely to oppose new limits on foreign imports than those who reported that economic conditions had gotten worse. However, the predicted probabilities for the 2004 model show that personal economic conditions did not have a significant impact on trade preferences. Respondents who believed that their personal finances had improved over the past year were $45 \%(+/-3 \%)$ more likely to oppose new limits on foreign imports while those who reported that their personal finances had gotten worse were also $45 \%(+/-4 \%)$ more likely to oppose new trade restrictions. Although economic conditions were not an important predictor of trade policy preferences, these predicted probabilities suggest that positive economic conditions were correlated with opposition to trade protectionism in a few of the time points in my analysis.

Education emerged as the strongest predictor of individual trade policy preferences in my analysis. Table 4 presents the predicted probabilities for the influence of education on trade preferences. For 1996, I found that individuals who received a bachelor's degree were $55 \%(+/-2 \%)$ more likely to oppose new limits on foreign imports while those who received an advanced degree were $62 \%(+/-3 \%)$ more likely. Furthermore, individuals who just a high school diploma were $43 \%$ (+/$2 \%$ ) more likely to support international trade while those with some college were only $31 \%(+/-3 \%)$ more likely. Similar probabilities appear for each logit model from 1998, 2004, and 2008. These numbers suggest that individuals who have completed a college degree are more likely to support international trade than those without a college education. The predicted probabilities for 2008 also suggest that people with 
less education are more likely to oppose international trade. Respondents who had attended college were $32 \%(+/-1 \%)$ more likely to oppose new limits while those with just an elementary education were only $10 \%(+/-3 \%)$ more likely.

\section{Conclusion}

The goals of this study were to determine whether evaluations about personal and national economic conditions influence individual trade policy preferences. Working with survey data collected by the ANES, I determined that perceived economic conditions have little influence on public support for new limits on foreign imports. I found that public support for international trade does not decline when people believe that economic conditions have gotten worse. Furthermore, support for international trade does not increase when people believe that economic conditions have improved. This study found that education and gender were more important determinants of trade policy preferences than economic conditions. I determined that men and survey respondents with a college education were more likely to oppose new limits on foreign imports. This preliminary evidence suggests that public attitudes about international trade are not endogenous to the economic system as changes within the economic environment did not produce changes in public opinion.

Even though my findings are inconclusive and may even suggest that economic conditions do not have a statistically significant influence on trade preferences, I believe that more research is needed. Ultimately, this endeavor is just the first step in a research agenda which examines how economic conditions influence public attitudes towards specific policy issues. Although little is currently 
known about this subject, future research needs to extend my analysis to other policy issues. Perhaps certain public attitudes towards certain policy issues are influenced by economic conditions while others are not. Although trade preferences may not be influence by perceived changes in the economic environment, there may be other policy issues that are. Policies concerning international aid, environmental regulation, and other concerns may be examined in future studies.

I also believe that future research needs to utilize more sophisticated methodologies which are able to better account for the influence of economic conditions on public opinion. Although this study used survey data to measure economic conditions, future research could utilize hierarchical modeling in order to look at the relationship between economic conditions and public opinion. Hierarchical analysis would allow researchers to examine trade preferences and account for the effects of state, regional, and national economic conditions. I also believe that future research should examine a broader time period and utilize timeseries survey data to look at changes in public opinion over time. These developments may provide new insights into the link between economic conditions and public opinion.

This study offers a number of important lessons for further research. It is important that scholars examine the impact of both personal and national economic conditions on public opinion. Given that individuals have their own financial environment that is often separate from economic conditions at the national level, it is important to consider both. In this analysis, national economic conditions had a 
greater influence on trade preferences than personal finances. It is also important that scholars account for the impact of political ideology on trade preferences. This study found that found that support for new limits on imports was not based on left-right distinctions or partisan affiliation. Therefore, future research must evaluate why political ideology and values had little impact on individual trade policy preferences. 


\section{$\underline{\text { References }}$}

Abramowitz, Alan I. 1987. "Candidate Choice Before the Convention: The Democrats in 1984." Political Behavior 9 (1): 49-61.

Achen, Christopher H. 1975. "Mass Political Attitudes and the Survey Response." American Political Science Review 69: 1218-1223.

Almond, Gabriel A. 1950. The American People and Foreign Policy. New York: Harcourt, Brace and Company.

Aspray, William, Frank Mayadas, and Moshe Y. Vardi. 2006. Globalization and Offshoring of Software. ACM Job Migration Task Force. Association for Computing Machinery.

Baier, Scott L. and Jeffrey H. Bergstrand. 2001. "The growth of world trade: tariffs, transport costs, and income similarity." Journal of International Economics 53: $1-27$.

Baker, Andy. 2005. "Who Wants to Globalize?” American Journal of Political Science 49 (4): 924-938.

Baldwin, Robert E. and Glen G. Cain. 1997. Shifts in U.S. Relative Wages: The Role of Trade, Technology and Factor Endowments. NBER Working Paper. No. 5934.

Bartels, Larry M. 1996. “Uninformed Votes: Information Effects in Presidential Elections.” American Journal of Political Science 40 (1): 194-230.

Bauer, Raymond A. Ithiel de Sola Pool, and Lewis Anthony Dexter. 1963. American Business and Public Policy. New York: Atherton Press. 
Blekesaune, Morten. 2007. "Economic Conditions and Public Attitudes to Welfare Policies.” European Sociological Review 23 (3): 393-403.

Blinder, Alan and Alan B. Krueger. 2004. "What does the public know about economic policy, and how does it know it?" NBER Working Paper. No. 10787.

Bradford, Scott C., Paul Grieco, and Gary C. Hufbauer. 2006. "The Payoff to America from Globalisation.” World Economy: 893-916.

Broda, Christian and David E. Weinstein. 2006. "Globalization and the Gains from Variety." Quarterly Journal of Economics (May): 541-585.

Burgoon, Brian and Michael J. Hiscox. (2004, September). The Mysterious Case of Female Protectionism: Gender Bias in the Attitudes and Politics of International Trade. Paper presented at the annual meeting of the American Political Science Association, Chicago, IL.

Campbell, Angus, Philip E. Converse, Warren E. Miller, and Donald E. Stokes. 1960. The American Voter. New York: Wiley.

Caspary, William R. 1970. “The 'Mood Theory': A Study of Public Opinion and Foreign Policy.” American Political Science Review 64: 536-547.

Converse, Philip E. 1964. "The Nature of Belief Systems in Mass Publics.” In Ideology and Discontent, edited by David E. Apter. New York: Free Press.

Cunat, Alejandro and Marco Maffezzoli. 2007. "Can Comparative Advantage Explain the Growth of US Trade?" Economic Journal 117: 583-602. 
Destler, I.M. 2005. American Trade Politics. Washington, DC: Institute for International Economics.

Duch, Raymond M., Harvey D. Palmer, and Christopher J. Anderson. 2000. "Heterogeneity in Perceptions of National Economic Condition." American Journal of Political Science 44 (4): 635-652.

Durr, Robert H. 1993. “What Moves Policy Sentiment?” American Political Science Review 87 (1): 158-17.

Hosmer, David W. and Stanley Lemeshow. 2000. Applied Logistic Regression. New York: John Wiley and Sons.

Edwards, Martin S. 2006. "Public Opinion regarding Economic and Cultural Globalization: Evidence from a Cross-National Survey." Review of International Political Economy 13 (4): 587-608.

Eichenber, Richard C. and Richard Stoll. 2003. “Representing Defense: Democratic Control of the Defense Budget in the United States and Western Europe.“ Journal of Conflict Resolution 47 (4): 399-422.

Enns, Peter K. and Paul M. Kellstedt. 2008. "Policy Mood and Political Sophistication: Why Everybody Moves Mood.” British Journal of Political Science 38: 433-454.

Erikson, Robert S., Michael B. MacKuen, and James A. Stimson. 2002. The Macro Polity. New York: Cambridge University Press.

Estevadeordal, Fanz and Alan Taylor (2003) "The Rise and Fall of World Trade 1870-1939" NBER Working Paper. No. 9318. 
Fox, John. 2008. Applied Regression Analysis and Generalized Linear Models. New York: Sage.

Frankel, Jeffrey A. and David Romer. 1999. "Does Trade Cause Growth?” American Economic Review 89 (3): 379-399.

Granzin, Kent L., Jeffrey D Brazell, and John J Painter. 1997. “An Examination of Influences Leading to Americans' Endorsement of the Policy of Free Trade.” Journal of Public Policy and Marketing 16 (1): 93-109.

Hainmuelle, Jens and Michael J. Hiscox. 2006. "Learning to Love Globalization: Education and Individual Attitudes toward International Trade." International Organization 60 (2): 469-498.

Hiscox, Michael J. 2006. "Through a Glass and Darkly: Attitudes toward International Trade and the Curious Effects of Issue Framing." International Organization 60 (3): 755-780.

Hoekstra, Valerie J. 2003. Public Reaction to Supreme Court Decisions. Cambridge: Cambridge University Press.

Hoffman, Michael. 2009. "What Explains Attitudes Across U.S. Trade Policies?" Public Choice 138: 447-460.

Holsti, Ole R. 1992. "Public Opinion and Foreign Policy: Challenges to the AlmondLippmann Consensus Mershon.” International Studies Review 36 (4): 439466.

Holsti, Ole. 1996. Public Opinion and American Foreign Policy. Ann Arbor: University of Michigan Press. 
Jelen, Ted G. 1994. "Religion and Foreign Policy Attitudes: Exploring the Effects of Denomination and Doctrine.” American Politics Research 22 (3): 382-400.

Johns, Robert. 2009. Tracing Foreign Policy Decisions: A Study of Citizens' Use of Heuristics." British Journal of Politics and International Relations 11: 574592.

Kam, Cindy D. and Yunju Nam. 2008. ” Reaching Out or Pulling Back:

Macroeconomic Conditions and Public Support for Social Welfare Spending." Political Behavior 30: 223-258.

Key, V.O. 1961. Public Opinion and American Democracy. New York: Alfred A Knopf.

Kinder, Donald R. and D. Roderick Kiewiet. 1979. "Economic Discontent and Political Behavior: The Role of Personal Grievances and Collective Economic Judgments in Congressional Voting." American Journal of Political Science 23 (3): 495-527.

Knopf, Jeffrey W. 1998. "How Rational Is "The Rational Public"? Evidence from U.S. Public Opinion on Military Spending." Journal of Conflict Resolution 42 (5): 544-571.

Krol, Robert. 2008. "Trade, Protectionism, and the U.S. Economy: Examining the Evidence.” Trade Briefing Paper No. 28. Cato Institute.

Lau, Richard R. and David P. Redlawsk. 2006. How Voters Decide. Cambridge: Cambridge University Press 
Lenway, Stefanie, Kathleen Rehbein, and Laura Starks. 1990. The Impact of Protection on Firm Wealth: The Experience of the Steel Industry. Southern Economic Journal 56: 1079--1093.

Lippmann, Walter. 1955. Public Opinion. New York: Macmillan.

Maggiotto, Michael A., and Eugene R. Wittkopf. 1981. “American Public Attitudes toward Foreign Policy.” International Studies Quarterly 25:601-631.

Lupia, Arthur. 1994. "Shortcuts Versus Encyclopedias: Information and Voting Behavior in California Insurance." American Political Science Review 88 (1): 63-76.

Mayda, Anna Maria and Dani Rodrik. 2001. "Why are some People (and Countries) more Protectionism than Others?" NBER Working Paper. No. 8461.

McClosky, Herbert and John Zaller. 1984. The American Ethos. Cambridge: Harvard University Press.

Meernik, James and Michael Ault. 2001. "Public Opinion and Support for U.S. Presidents' Foreign Policies.” American Politics Research 29 (4): 352-373.

Moe, Terry M. 2001. Schools, Vouchers, and American Public Opinion. New York: Brookings Institution Press.

Mueller, John E. 1971. "Trends in Popular Support for the Wars in Korea and Vietnam.” American Political Science Review 65 (2): 358-375.

Nelson, Thomas E. and Zoe M. Oxley. 1999. "Issue Framing Effects on Belief Importance and Opinion.” Journal of Politics 61 (4): 1040-1067. 
Nie, Norman H., Sidney Verba, and John R. Petrocik. 1979. The Changing American Voter. Cambridge: Harvard University Press.

O’Rourke, Devin H. 2003. "Heckscher-Ohlin Theory and Individual Attitudes Toward Globalization.” NBER Working Paper. No. 9872.

O’Rourke, Kevin H. and Richard Sinnott. 2001. “The Determinants of Individual Trade Policy Preferences: International Survey Evidence.” Brookings Trade Forum: 157-196.

Page, Benjamin I. and Robert Y. Shapiro. 1982. “Changes in Americans' Policy Preferences, 1935-1979." Public Opinion Quarterly 46 (1): 24-42.

Page, Benjamin I., Robert Y. Shapiro, and Glenn R. Dempsey. 1987. "What Moves Public Opinion?" American Political Science Review 81 (1): 23-43.

Page, Benjamin I., and Robert Y. Shapiro. 1991. The Rational Public. Chicago: University of Chicago Press.

Peffley, Mark A. and Jon Hurwitz. 1992. "International Events and Foreign Policy Beliefs: Public Responses to Changing Soviet-U.S. Relations.” American Journal of Political Science 36: 431-461.

Popkin, Samuel L. 1994. The Reasoning Voter. Chicago: University of Chicago Press.

Scheve, Kenneth F. and Matthew J. Slaughter. 2001a. "What determines individual trade-policy preferences?" Journal of International Economics 54: 267-292.

Scheve, Kenneth F. and Mathew J. Slaughter. 2001b. Globalization and the Perceptions of American Workers. Washington DC: Institute for International Economics. 
Scheve, Kenneth F. and Matthew J. Slaughter. 2007. “A New Deal For Globalization." Foreign Affairs 86 (4): 34-47.

Shaw, Daron R. 1999. “A Study of Presidential Campaign Event Effects from 1952 to 1992." Journal of Politics 61 (2): 387-422.

Stevenson, Randolph T. 2001. “The Economy and Policy Mood: A Fundamental Dynamic of Democratic Politics?” American Journal of Political Science 45 (3): 620-633.

Stimson, James A. 1998. Public Opinion in America: Moods, Cycles, and Swings. Boulder: Westview Press.

Verba, Sidney, et al. 1967. "Public Opinion and the War in Vietnam." American Political Science Review 61: 317-333.

Wacziarg, Romain and Karen H. Welch. 2008. “Trade Liberalization and Growth: New Evidence.” World Bank Economic Review 22 (2): 187-231.

Walstad, Wiiam B. 1997. "The Effect of Economic Knowledge on Public Opinion of Economic Issues.” Journal of Economic Education 28 (3): 195-205.

Wlezien, Christopher. 1995. "The Public as Thermostat: Dynamics of Preferences for Spending.” American Journal of Political Science 39 (4): 981-1000.

World Bank (2004) World Development Indicators Washington DC: World Bank. 
Table 1: Descriptive Statistics

\begin{tabular}{|lcccc|}
\hline ANES 1996 & Mean & Median & Mode & $\mathrm{N}$ \\
\hline Trade Opinion & 1.46 & 1.0 & 1 & 846 \\
\hline Finances & 1.88 & 2.0 & 1 & 1707 \\
\hline Economy & 1.77 & 2 & 2 & 1698 \\
\hline ANES 1998 & Mean & Median & Mode & $\mathrm{N}$ \\
\hline Trade Opinion & 1.47 & 1.0 & 1 & 754 \\
\hline Finances & 1.75 & 1.0 & 1 & 1279 \\
\hline Economy & 1.67 & 2.0 & 1 & 1261 \\
\hline ANES 2000 & Mean & Median & Mode & $\mathrm{N}$ \\
\hline Trade Opinion & 1.51 & 2.0 & 2 & 1306 \\
\hline Finances & 2.18 & 3.0 & 3 & 924 \\
\hline Economy & 1.75 & 2.0 & 2 & 896 \\
\hline ANES 2004 & Mean & Median & Mode & $\mathrm{N}$ \\
\hline Trade Opinion & 1.44 & 1.0 & 1 & 609 \\
\hline Finances & 1.81 & 2.0 & 1 & 1204 \\
\hline Economy & 2.22 & 2.0 & 3 & 1198 \\
\hline ANES 2008 & Mean & Median & Mode & $\mathrm{N}$ \\
\hline Trade Opinion & 1.31 & 1.0 & 1 & 1018 \\
\hline Finances & 1.85 & 2.0 & 2 & 3211 \\
\hline Economy & 2.86 & 3.0 & 3 & 2311 \\
\hline
\end{tabular}


Table 2: Logistic Regression Predicting Trade Preferences by Economic Conditions

\begin{tabular}{|c|c|c|c|c|c|}
\hline & $\frac{\text { Model } 1}{1996}$ & $\frac{\text { Model } 2}{1998}$ & $\frac{\text { Model } 3}{2000}$ & $\frac{\text { Model } 4}{2004}$ & $\frac{\text { Model } 5}{2008}$ \\
\hline Age & $\begin{array}{l}-0.009 \\
(0.006)\end{array}$ & $\begin{array}{c}-0.021^{* *} \\
(0.006)\end{array}$ & $\begin{array}{c}-0.031 \\
(0.018)\end{array}$ & $\begin{array}{c}-0.014 * * \\
(0.007)\end{array}$ & $\begin{array}{c}0.002 \\
(0.005)\end{array}$ \\
\hline Education & $\begin{array}{c}-0.258 * * \\
(0.049)\end{array}$ & $\begin{array}{c}-0.317 * * \\
(0.051)\end{array}$ & $\begin{array}{l}-0.267 \\
(0.142)\end{array}$ & $\begin{array}{c}-0.166^{* *} \\
(0.056)\end{array}$ & $\begin{array}{c}0.157 * * \\
(0.034)\end{array}$ \\
\hline Finances & $\begin{array}{c}-0.208 * * \\
(0.098)\end{array}$ & $\begin{array}{l}-0.038 \\
(0.100)\end{array}$ & $\begin{array}{c}0.081 \\
(0.243)\end{array}$ & $\begin{array}{c}0.004 \\
(0.130)\end{array}$ & $\begin{array}{l}-0.122 \\
(0.115)\end{array}$ \\
\hline Economy & $\begin{array}{c}-0.465 * * \\
(0.120)\end{array}$ & $\begin{array}{c}0.085 \\
(0.113)\end{array}$ & $\begin{array}{c}-0.663 \\
(0.358)\end{array}$ & $\begin{array}{c}-0.376^{* *} \\
(0.131)\end{array}$ & $\begin{array}{l}-0.329 \\
(0.185)\end{array}$ \\
\hline Partisan & $\begin{array}{c}0.196 \\
(0.108)\end{array}$ & $\begin{array}{c}0.275^{* *} * \\
(0.106)\end{array}$ & $\begin{array}{c}0.505 \\
(0.329)\end{array}$ & $\begin{array}{c}0.225 \\
(0.115)\end{array}$ & $\begin{array}{c}-0.047 \\
(0.107)\end{array}$ \\
\hline Employment & $\begin{array}{c}0.051 \\
(0.064)\end{array}$ & $\begin{array}{l}-0.038 \\
(0.057)\end{array}$ & $\begin{array}{c}0.031 \\
(0.152)\end{array}$ & $\begin{array}{c}-0.136 * * \\
(0.066)\end{array}$ & $\begin{array}{c}0.030 \\
(0.053)\end{array}$ \\
\hline Union & $\begin{array}{c}0.049 \\
(0.201)\end{array}$ & $\begin{array}{c}0.094 \\
(0.218)\end{array}$ & $\begin{array}{c}0.432 \\
(0.668)\end{array}$ & $\begin{array}{c}0.346 \\
(0.257)\end{array}$ & $\begin{array}{c}0.049 \\
(0.211)\end{array}$ \\
\hline Home & $\begin{array}{c}0.369 \\
(0.195)\end{array}$ & $\begin{array}{c}0.216 \\
(0.191)\end{array}$ & $\begin{array}{l}-0.027 \\
(0.563)\end{array}$ & $\begin{array}{l}-0.282 \\
(0.247)\end{array}$ & $\begin{array}{c}0.332 \\
(0.173)\end{array}$ \\
\hline Market & $\begin{array}{c}0.568 * * \\
(0.174)\end{array}$ & - - & $\begin{array}{c}0.083 \\
(0.477)\end{array}$ & $\begin{array}{c}1.034 * * \\
(0.205)\end{array}$ & $\begin{array}{c}0.040 \\
(0.174)\end{array}$ \\
\hline Race & $\begin{array}{c}0.187 \\
(0.157)\end{array}$ & $\begin{array}{l}-0.154 \\
(0.147)\end{array}$ & $\begin{array}{l}-0.287 \\
(0.355)\end{array}$ & $\begin{array}{c}0.061 \\
(0.078)\end{array}$ & $\begin{array}{c}0.096 \\
(0.105)\end{array}$ \\
\hline Income & $\begin{array}{c}0.197 * * \\
(0.062)\end{array}$ & $\begin{array}{c}0.043 \\
(0.066)\end{array}$ & $\begin{array}{c}0.196 \\
(0.207)\end{array}$ & $\begin{array}{l}-0.102 \\
(0.076)\end{array}$ & $\begin{array}{c}0.013 \\
(0.057)\end{array}$ \\
\hline Gender & -- & $\begin{array}{c}-0.353 * * \\
(0.170)\end{array}$ & $\begin{array}{l}-0.418 \\
(0.445)\end{array}$ & $\begin{array}{c}-0.509 * * \\
(0.197)\end{array}$ & $\begin{array}{c}-0.365^{* *} \\
(0.155)\end{array}$ \\
\hline Pseudo R-square & 0.20 & 0.13 & 0.18 & 0.20 & 0.10 \\
\hline Chi Square & 128.75 & 71.89 & 15.68 & 84.61 & 141.70 \\
\hline Log Likelihood & -469.73 & -442.23 & -65.46 & -316.59 & -1137.99 \\
\hline $\mathrm{N}$ & 846 & 754 & 1306 & 609 & 1018 \\
\hline
\end{tabular}

Source $=$ American National Election Study

Notes $=$ Coefficients are logit coefficients and were estimated for each survey year; standard errors are in parentheses. The dependent variable, trade opinion, is regressed on the entire set of independent variables. "**" indicates statistical significance at a 0.05 level or better. "- -" indicates that a survey question for that topic was not included within the ANES survey for that year. 
Table 3: Predicted Probabilities of Trade Preferences Based on Economic Conditions

\begin{tabular}{|c|c|ll|}
\hline ANES 1996 & \multicolumn{3}{|l|}{} \\
\hline Finances - better [1] & $\begin{array}{l}50 \% \\
(2.8)\end{array}$ & Economy - better [1] & $\begin{array}{l}54 \% \\
(2.8)\end{array}$ \\
\hline Finances - same [2] & $\begin{array}{l}45 \% \\
(1.9)\end{array}$ & Economy - worse [2] & $\begin{array}{l}42 \% \\
(2.1)\end{array}$ \\
\hline Finances - worse [3] & $\begin{array}{c}40 \% \\
(3)\end{array}$ & Economy - same [3] & $\begin{array}{l}32 \% \\
(3.8)\end{array}$ \\
\hline ANES 2004 & & & \\
\hline Finances - better [1]* & $\begin{array}{l}45 \% \\
(3.3)\end{array}$ & Economy - better [1] & $\begin{array}{l}56 \% \\
(4.3)\end{array}$ \\
\hline Finances - same [2]* & $\begin{array}{l}45 \% \\
(2.5)\end{array}$ & Economy - worse [2] & $\begin{array}{l}47 \% \\
(2.4)\end{array}$ \\
\hline Finances - worse [3]* & $\begin{array}{l}45 \% \\
(4.6)\end{array}$ & Economy - same [3] & $\begin{array}{l}38 \% \\
(3.5)\end{array}$ \\
\hline
\end{tabular}

Source $=$ American National Election Study

Note $=$ Shows the predicted probabilities of support for new limits on imports based on attitudes regarding economic conditions. Predicted probabilities are estimated with all other continuous variables held at their means. Standard deviations are located within parentheses and are percentages. The coding for each of the variables is located within brackets. "*” indicates that the variable personal was not statistically significant at a $5 \%$ level. 
Table 4: Predicted Probabilities of Trade Preferences Based on Education

\begin{tabular}{|c|c|c|c|}
\hline & ANES 1996 & $\underline{\text { ANES } 1998}$ & ANES 2004 \\
\hline Advanced Degree [1] & $\begin{array}{l}62 \% \\
(3.4)\end{array}$ & $\begin{array}{l}67 \% \\
(3.3)\end{array}$ & $\begin{array}{l}56 \% \\
(4.2)\end{array}$ \\
\hline Bachelors Degree [2] & $\begin{array}{l}55 \% \\
(2.6)\end{array}$ & $\begin{array}{l}59 \% \\
(2.7)\end{array}$ & $\begin{array}{l}52 \% \\
(3.2)\end{array}$ \\
\hline $\begin{array}{l}\text { Did not Complete } \\
\text { High School [3] }\end{array}$ & $\begin{array}{l}49 \% \\
(2.0)\end{array}$ & $\begin{array}{l}51 \% \\
(2.1)\end{array}$ & $\begin{array}{l}48 \% \\
(2.5)\end{array}$ \\
\hline High School Diploma [4] & $\begin{array}{l}43 \% \\
(2.0)\end{array}$ & $\begin{array}{l}44 \% \\
(2.0)\end{array}$ & $\begin{array}{l}44 \% \\
(2.4)\end{array}$ \\
\hline $\begin{array}{c}\text { Junior or Community } \\
\text { College Degree [5] }\end{array}$ & $\begin{array}{l}37 \% \\
(2.4)\end{array}$ & $\begin{array}{l}36 \% \\
(2.5)\end{array}$ & $\begin{array}{l}39 \% \\
(2.9)\end{array}$ \\
\hline Some College [6] & $\begin{array}{l}31 \% \\
(3.1)\end{array}$ & $\begin{array}{l}29 \% \\
(3.1)\end{array}$ & $\begin{array}{l}36 \% \\
(3.9)\end{array}$ \\
\hline
\end{tabular}

Source $=$ American National Election Study

Note $=$ Shows the predicted probabilities of support for new limits on imports based on education. Predicted probabilities are estimated with all other continuous variables held at their means. Standard deviations are located within parentheses and are percentages. The coding for each of the variables is located within brackets. The probabilities for ANES 2008 are not presented in this table because the coding scheme is different. 